\title{
Modification of gene expression of the small airway epithelium in response to cigarette smoking
}

\author{
Ben-Gary Harvey • Adriana Heguy • Philip L. Leopold •
}

Brendan J. Carolan - Barbara Ferris •

Ronald G. Crystal

Published online: 29 May 2008

(C) Springer-Verlag 2008

Erratum to: J Mol Med (2007) 85:39-53

DOI 10.1007/s10109-006-0103-Z

In the methods section of the paper, the diameter of the cytology brush used to collect airway epithelial cells was incorrectly stated to be $1.2 \mathrm{~mm}$ (page 41, paragraph 1, line 5). In fact, the brush used had a diameter of $2 \mathrm{~mm}$.

The online version of the original article can be found at http://dx.doi. org/10.1007/s00109-006-0103-z.

B.-G. Harvey • R. G. Crystal $(\bowtie)$

Division of Pulmonary and Critical Care Medicine,

Weill Medical College of Cornell University,

New York, NY, USA

e-mail: geneticmedicine@med.cornell.edu

\footnotetext{
A. Heguy • P. L. Leopold • B. J. Carolan • B. Ferris · R. G. Crystal Department of Genetic Medicine,

Weill Medical College of Cornell University,

515 East 71st Street, S-1000,

New York, NY 10021, USA
} 